\title{
DEVELOPING LEARNING MATERIALS BASED ON TRAINING WITHIN INDUSTRY (TWI) TO IMPROVE THE BUILDING CONSTRUCTION STUDENT'S LEARNING OUTCOMES
}

\author{
Sugiyanto, Made Wena, \& Isnandar \\ Universitas Negeri Malang, Jl. Semarang 5 Malang 65145 \\ e-mail: made.wena.ft@um.ac.id
}

\begin{abstract}
Developing Learning Materials Based on Training Within Industry (TWI) to Improve the Building Construction Student's Learning Outcomes.This second study aims to test significances differences between (1) using teaching materials with TWI method and the conventional method; (2) the high achievement motivation students and the low achievement motivation students; and (3) learning structures (TWI method and conventional method) and the high achievement motivation and the low achievement motivation toward the students' learning outcomes. This study is an experimental research for students who take the Bricklaying and Concrete Practice lesson in an academic year. The hypothesis test uses two-way variance analysis (ANAVA) to find out the differences in the mean between cells (A and B). The results showed that there were significant differences in the students' learning outcome between (1) the TWI teaching materials and conventional method; (2) the students who have the high achievement motivation and the students who have the low achievement motivation. Furthermore, there were significant interactions between factor of giving the vocational work practices and motivation toward the students' learning outcomes.
\end{abstract}

Keywords: Teaching Materials, Vocational Work Practices (TWI), Learning Outcomes

\begin{abstract}
Abstrak: Mengembangkan Bahan Pembelajaran Berdasarkan Pelatihan Dalam Industri (Training Within Industry) untuk Meningkatkan Hasil Belajar Siswa Konstruksi Bangunan. Penelitian ini bertujuan untuk menguji perbedaan signifikansi antara (1) penggunaan bahan ajar dengan metode TWI dan metode konvensional; (2) siswa motivasi berprestasi tinggi dan siswa motivasi berprestasi rendah; dan (3) struktur pembelajaran (metode TWI dan metode konvensional) dan motivasi berprestasi tinggi dan motivasi berprestasi rendah terhadap hasil belajar siswa. Penelitian ini adalah penelitian eksperimental untuk siswa yang mengambil pelajaran Bricklaying dan Praktek Beton di satu tahun akademik. Uji hipotesis menggunakan analisis varian dua arah (ANAVA) untuk mengetahui perbedaan ratarata antara sel (A dan B). Hasil penelitian menunjukkan bahwa ada perbedaan yang signifikan dalam hasil belajar siswa antara (1) bahan ajar TWI dan metode konvensional; (2) siswa yang memiliki motivasi berprestasi tinggi dan siswa yang memiliki motivasi berprestasi rendah. Selain itu, ada interaksi yang signifikan antara faktor pemberian praktik kerja kejuruan dan motivasi terhadap hasil belajar siswa.
\end{abstract}

Kata kunci: Bahan Ajar, Praktek Kerja Kejuruan (TWI), Hasil Belajar

Indonesia must face the emerging internal and external worldwide challenge (Depdiknas, 2013). The external challenges are advanced technology, information, globalization and various environmental issues, as well as the education internationalization.

As consequence, it is necessary to improve the quality of the Indonesian's education system. According to Depdiknas (2013), there are three fac- tors need to be strengthened: (a) curriculum system, (b) learning styles, and (3) learning materials. Those reinforcement needs to be done at all levels of education, including Vocational High School (VHS). Ideally, teaching-learning activities in VHS are not only focused on the development of cognitive skill but also the strong connection between the cognitive, affective and psychomotor aspects (Suparno, 
2009). However, in order to achieve a good balance of learning objectives, the learning facilities (i.e. Learning materials) should be provided. The teaching materials may simultaneously help in developing cognitive, affective and psychomotor skill.

Daly et al. (2009) revealed that the VHS teachers should be able to develop their creativity in teaching in order to develop the students' learning outcomes. The appropriate teaching materials using the Training Within Industry (TWI) method may solve those problems. The use of TWI may improve the students' the learning outcomes. In addition, the use of this method might encourage the students to have more comprehensive understandings related to the learning materials (Joice \& Weil, 2005; Wren, et al., 2009; Wena, 2012).

In the first research, the developed teaching material consists of the teaching-learning materials, the teacher's guide, and the audio-visual media which is designed with the TWI method. Based on the individual test by the experts, learning experts, lecturers, it is stated that the teaching material is valid. However, the validity of the three parts of the teaching materials is done through the expert testing and individual testing. As a result, the empirical test (field) for the materials is urgent to do.

The empirical test/small group test is required is to find out the reliability of the teaching materials compared with the conventional learning. If the TWI teaching materials are better than the conventional teaching materials, the TWI teaching materials will be feasible to use in Construction Engineering Department. Vis-a-vis, it will need to develop the teaching materials with other methods.

This research is urgent to be conduct. It may to provide empirical findings for the improvement of the learning quality using the TWI approach. In a more detail, this study aims to: (1) test the significant differences in the students' learning outcomes between the TWI teaching materials and the conventional teaching materials. (2) test the significant differences in the learning outcomes between the students with high achievement motivation and the students with low achievement motivation; and (3) the significant interactions between learning structures (TWI method and conventional method) and high-low level of motivation toward learning outcomes.

\section{RESEARCH METHOD}

The research is conducted at the State Vocational High School 1 Singosari Malang. The study involves the two classes of second grader of Building and Construction Department in Bricklaying And Concrete Practice lesson in the 2018/2019 academic year. In order to obtain the same group, both classes are classified based on their grades from first to second semester. The next step is randomly determine the experimental and control class, consist of 29 and 32 students respectively.

The research used is $2 \times 2$ factorial design. Furthermore, the study used various instruments such as syllabus, RPP, students' sheets, teacher's guide, questionnaire about motivation, and learning outcomes test.

Test and non-test techniques are used to collect the data. The test is used to obtain the data of learning outcomes, while the questionnaire, as nontest instrument, is to obtain the data of the achievement motivation. Furthermore, this study consists of several stages: (1) gathering the sample teachers for initial discussions with the researchers to synchronize the learning purposes in this research; (2) giving training the sample teachers to understand the concepts of the TWI method; (3) conducting a pre-test on the experimental class and control class; (4) conducting the teaching-learning process in the experimental group and in the control group; (5) conducting post-tests on the experimental class and control class; (6) conducting Focus Group Discussion (FGD) to discuss and solve various problems that have been found in the teaching-learning; and (7) giving corrections and revisions based on the FGD results.

The result will be analyzed using two-way of Variance Analysis (Anava). The significance level $(\alpha)$ that used is 0.05 or $5 \%$. The result of the hypothesis test is determined by the criteria: If Sig. > 0,05 , the null hypothesis $(\mathrm{H} 0)$ is rejected.

\section{RESULT AND DISCUSSION}

For 61 students, the average of the learning outcomes in TWI teaching material is 79.63. It was higher than the average learning outcomes of the conventional teaching materials group with the average of 73.58. The result was described in Table 1.

Table 1. Description of Learning Outcomes Based on Type of Treatment in the Group

\begin{tabular}{lccc}
\hline Group Treatment & Mean & Sd & N \\
\hline Conventional & 73,58 & 3,15 & 29 \\
\hline TWI & 79,63 & 3,62 & 32 \\
\hline
\end{tabular}


The 29 of 61 students were in the conventional teaching materials group. The students who have the high achievement motivation was 9 students and the students who have the low achievement motivation is 20 students. While in TWI teaching materials group, the students who have the high achievement motivation was 22 students and the students who have the low achievement motivation was 10 students. The description can be seen in Table 2 .

Table 2. Description of Learning Outcomes Based on Achievement Motivation Level

\begin{tabular}{lcccc}
\hline \multicolumn{1}{c}{$\begin{array}{c}\text { Group } \\
\text { Treatment }\end{array}$} & $\begin{array}{c}\text { Achievement } \\
\text { Motivation } \\
\text { Group }\end{array}$ & Mean & Sd & N \\
\hline $\begin{array}{l}\text { Conven- } \\
\text { tional }\end{array}$ & High & 72,61 & 2,10 & 20 \\
\cline { 2 - 5 } TWI & Low & 75,20 & 4,00 & 9 \\
\cline { 2 - 5 } & High & 78,86 & 4,78 & 10 \\
\hline
\end{tabular}

Before conducting the variant analysis for hypothesis testing, the variant analysis of Levene's Test of Equality was conducted to determine the homogeneity of the score of the learning outcomes of each group.It can be concluded that the result data is homogenous. The mean of the students' learning outcomes is presented in Table 3.

Table 3. Averege of Learning Outcomes

\begin{tabular}{lllcc}
\hline Group & $\begin{array}{l}\text { Achievement } \\
\text { Motivation }\end{array}$ & Mean & $\begin{array}{c}\text { Std. } \\
\text { Deviation }\end{array}$ & N \\
\hline \multirow{2}{*}{$\begin{array}{l}\text { Conven- } \\
\text { tional }\end{array}$} & $\begin{array}{l}\text { Low } \\
\text { Motivation }\end{array}$ & 72.61 & 2.10 & 20 \\
\cline { 2 - 5 } & $\begin{array}{l}\text { High } \\
\text { Motivation }\end{array}$ & 75.20 & 4.00 & 9 \\
\cline { 2 - 5 } & Total & 73.58 & 3.15 & 29 \\
\hline \multirow{2}{*}{ TWI } & $\begin{array}{l}\text { Low } \\
\text { Motivation }\end{array}$ & 78.86 & 4.78 & 10 \\
\cline { 2 - 5 } & $\begin{array}{l}\text { High } \\
\text { Motivation }\end{array}$ & 80.41 & 1.79 & 22 \\
\cline { 2 - 5 } & Total & 79.63 & 3.62 & 32 \\
\hline
\end{tabular}

From the description of each hypothesis, the conclusions can be presented as following sections

\section{The Use of TWI Learning to Improve the Students' Learning Outcomes}

Based on the results of the 1st Hypothesis Test, the group TWI learning group was better than the conventional learning group. Giving treatment in the learning process had influenced significantly on the students' learning outcomes.

These findings have been proved with SPSS's result. The result of the mean of TWI group's learning outcomes (without considering the achievement motivation) was 79.63. So, it is better than the conventional group with the mean of 73.58 .

Arafat (2017) stated that the learning can facilitate the learning process if it is supported with the internal events that related to the good information process which is focused on the effective and efficient the teaching-learning process. Manurung \& Jaselton (2016) said that the learning outcomes is a complex process that occurs because of the interactions that changed everyone's behavior, knowledge, skills, and attitudes. Sathiyapriya \& Vivek (2013) stated that the framework is needed to achieve the external integration of TWI program efficiently and to become one of the most sustainable solutions for outstanding results. Pratama \& Bintang (2015) concluded that in the teachinglearning process of electric motor installation by using TWI (Training Within Industry) the produced the better learning outcomes. Therefore, it can guide the students to learn more actively while the teacher monitor the students from the beginning to the end of the lesson.

The implementation of TWI in the teachinglearning process, has more significant results than the conventional teaching-learning process. There is a good learning outcome in the TWI learning. So, TWI learning can help the students to achieve the learning objectives. The TWI is a type of direct learning (Direct Instruction). Direct learning is characterized by five important points; the teacher begins teaching-learning process by explaining the purpose of learning and background study, preparing the students to receive the teacher's explanations, giving the materials or demonstrations, giving exercises, and feedback on students' success. All these factors are a reflection of the TWI learning model. Direct Instruction emphasizes the teacher's demonstration strategies, integrated training strategies, and independent practice or application of learning strategies. Direct Instruction can be lectures, demonstrations, training or practices, and group work. Direct Instruction is used to convey the lessons from the teacher directly to the students.

Based on the supporting journals and the result of the study that have conducted, it can be concluded that TWI learning can improve the students' learning outcomes. In the implementation of TWI, the students were required to demonstrate actively what has been given by the teacher. The students 
who do not understand indirectly will ask questions to the teacher as a facilitator in the classroom.

\section{The Effect of Achievement Motivation towards Learning Outcomes}

Based on the result of the 2nd Hypothesis Test, both in the TWI learning group and conventional learning group with high achievement motivation have the higher learning outcomes than the group learning achievement with low achievement motivation.

The mean of learning outcomes of the group with high achievement motivation in the TWI learning $(=80.41)$ was higher than the mean of the low achievement motivation $(=78.86)$. While the mean the learning outcomes of conventional learning groups with high achievement motivation $(=75.20)$ was higher than with the low achievement motivation $(=72.61)$.

Based on the mean of significant learning outcomes between the two groups and their each achievement motivation, it can be concluded that the group with high achievement motivation have obtained the higher learning outcomes compared to those with low achievement motivation in all groups (both TWI and conventional learning). As a result, the learning outcome is based on the variation in the achievement motivation level in the treatment group.

Myers (2011) said that each individual's achievement motivation is different from the others. There are several factors that influenced one's achievement motivation, such as family environment, university environment and friend's environment. Kusurkar et al. (2013) stated that the motivation has a significant effect on the academic performance. The difference of gender can influence the achievement motivation. Therefore, to build the motivation for students with low motivation in learning group is to provide the learning facility and give rewards during the teaching-learning process.

Purwanto (2014) examined that the contribution of three elements of motivational achievers, as follows: (1) the task score; (2) self-efficacy; and (3) goal orientation. The results showed that all three elements are reliable models. The results are based on the findings of data analysis of the task score, self-efficacy, and goal orientation in which these are significant for achievement motivation.

Retnowati et al. (2016) concluded that the academic achievement and achievement motivation of undergraduate students of Geography Education State University of Malang is influenced by some internal and external factors. Internal factors that come from within or the student itself, such as interest and motivation. The external factors are learning facilities, social environment, and family supports.

Achievement motivation is formed from the efforts and effective learning actions so it can optimize its potential. Learning activities will work if the individual is motivated to learn. The achievement motivation can generate ideas or thoughts, wishes, and efforts to perform learning activities effectively and efficiently. The high achievement motivation is the better academic achievement. The low achievement motivation is the poor academic achievement.

If you have the high achievement motivation result, it will get high academic achievement. If you have the low-achievement motivation, otherwise tend to get the low academic achievement. This is in line with the opinion of Biggs and Tefler (in Hamdu \& Agustina, 2011). They stated that the lack of motivation or no motivation in the learning will get low quality of learning outcomes. Thus, there is a positive influence between achievement motivation toward the achievement of learning outcomes.

\section{Interaction between TWI Learning and Achievement Motivation toward Learning Outcomes.}

Based on the result of the 3rd Hypothesis Testing, there are the interactions between the first factor and the second factor. There is an interaction between TWI learning and achievement motivation toward learning outcomes. There is a significant interaction between the three factors to the learning outcomes in this study. The result showed that the factors of giving method in the group and achievement motivation factors do not affect separately/ individually, but the two factors are interacted together in influencing the learning outcomes.

In order to know the group that has to get the most advantages of the implementation of TWI learning. The mean comparison is conducted related to the learning outcomes from TWI learning group and conventional learning. Recapitulation of learning outcomes is outlined in Table 4.

Table 4 showed that the highest difference in learning outcomes is found in TWI learning group with high achievement motivation $(80,41-75,20=$ 
$5,21)$. Thus, this group got the most advantages from the implementation of TWI learning. In the other words, this group have the most effective learning.

Table 4. Mean Comparison of Learning Outcomes Based on Treatment Group and Achievement Motivation

\begin{tabular}{clc}
\hline \multirow{2}{*}{ Group } & \multicolumn{1}{c}{ Achievement Motivation } & Mean \\
\hline \multirow{3}{*}{ Conventional } & Low Motivation & 72.61 \\
\cline { 2 - 3 } & High Motivation & 75.20 \\
\cline { 2 - 3 } & Total & 73.58 \\
\hline \multirow{3}{*}{ TWI } & Low Motivation & 78.86 \\
\cline { 2 - 3 } & High Motivation & 80.41 \\
\cline { 2 - 3 } & Total & 79.63 \\
\hline
\end{tabular}

These result is in line with the results of research Gota (2012) which concluded that aside from the students' gender, the achievement motivation has a direct and significant influence on students' academic achievement. The students' achievement motivation in learning can facilitate the learning process in the classroom. For the students who have motivation will encourage themselves in learning. Based on Nicholls' opinions (in Alderman, 2004), the high achievement motivation is one aspect of one's intellectual developments. The students who have high motivation will have high efforts to achieve the achievement.

The interaction between the implementation of TWI learning and achievement motivation in the learning outcomes gives the implication for achievement motivation that made a reference to the improvement of learning outcomes in the TWI learning. The implementation of TWI learning and achievement motivation has an important role in determining the students' learning outcomes. The learning process by using TWI learning and conventional learning is very different in the implementation.

The process of TWI learning provides new knowledge for the students through class activities which more active than conventional learning method. The TWI learning encourages the students to interact, teach, and discuss. So for the group of students who have low achievement motivation, they will get high learning outcomes with the implementation of TWI learning. This statement is in line with the research of Arafat (2017). He stated that the learning outcomes of learners' skills by using the Training Within Industry (TWI) learning model have significant results because TWI learning orientation is based on the practices that emphasize skills acquisition.

\section{CONCLUSIONS AND SUGGESTIONS}

Conclusions from the results of hypothesis test and discussion's result of the study can be described as follows: (1) there were significant differences in the students' learning outcome between TWI learning group and conventional learning group; (2) there were significant difference of learning outcomes between the students who have high achievement motivation with the student who have low achievement motivation. The results showed that the achievement motivation plays an important role in determining the treatment giving and improvement of the learning outcomes; and (3) there were significant interactions between the factors of giving learning in TWI learning group and the achievement motivation to the learning outcomes. The highest mean in the learning outcomes was the group of students who have low achievement motivation. It was proven based on the difference in the calculation result of the use of TWI learning and conventional learning with the highest learning outcomes. This result showed that the implementation of TWI learning affected the students' learning outcomes to get better results.

Based on the findings in the study, there are some suggestions as follow: (1) the implementation of TWI learning can be an alternative to deliver the teaching materials to improve interactions, self-confidence, the students' independence in expressing their opinions and to improve learning outcomes; (2) the implementation of the learning model should consider the achievement motivation that the students already have. This is necessary in order to correspond the student's condition and can be useful for the learning outcomes; (3) for the lecturers, they should always provide motivation and pay attention to the students' learning style in the class. The motivation is also very influential on the students' learning outcomes; (4) for the next researcher, they can continue this study by implementing the methods in a better way and using the variables that have the relationship with the variables that already have in this study. 


\section{REFERENCES}

Alderman, M.K. 2004. Motivation For Achievement: Possibilities For Teaching And Learning (2nd, ed). New Jersey: Lawrence Erlbaum Associates.

Arafat, M.Y. 2017. Peningkatan Hasil Belajar Keterampilan dengan Menggunakan Model Pembelajaran Training Within Industry (TWI). PEDAGOGIKA: Jurnal Ilmu Pendidikan, 8 (3): 309319.

Daly, S.R., Mosyjowski, E.A. \& Seifert, C.M. 2014. Teaching Creativity in Engineering Courses. Journal of Engineering Education, 103 (3): 417449.

Departemen Pendidikan dan Kebudayaan. 2013. Peraturan Menteri Pendidikan Pendidikan dan Kebudayaan Republik Indonesia Nomor 70 Tahun 2013 Tentang Kerangka Dasar dan Struktur Kurikulum sekolah Menengah Kejuruan/Madrasah Aliyah Kejuruan. Jakarta: Kemdikbud.

Gota, A.A. 2012. Effects of parenting styles, academic self-efficacy, and achievement motivation on the academic achievement of university students in Ethiopia. Unpublished Ph.D. Thesis. Perth: Edith Cowan University.

Hamdu, G. \& Agustina, L. 2011. Pengaruh Motivasi Belajar Siswa Terhadap Pestasi Belajar Ipa Di Sekolah Dasar (Studi Kasus terhadap Siswa Kelas IV SDN Tarumanagara Kecamatan Tawang Kota Tasikmalaya). Jurnal Penelitian Pendidikan, 12 (1): 90-96.

Joice, B. \& Weil, M. 2006. Models of Teaching. New Jersey: Prentice Hall, Inc.

Kusurkar, R.A., ten Cate, O., Vos, C.M.P., \& Westers, P. 2013. How motivation affects academic performance: A structural equation modelling analysis. Advances in Health Science Education, 18 (1): 57-69.

Manurung, J. \& Jaselton. 2016. Implementasi Strategi Pembelajaran Ranah Motorik Model TWI Ter- hadap Peningkatan Hasil Belajar Siswa Pada Kompotensi Pembelajaran Memahami Pengukuran Komponen Elektronika Pada Siswa Kelas X TITL A SMK Negeri 1 Lubuk Pakam. Jurnal Generasi Kampus, 9 (2): 221-240.

Myers, D.G. 2011. Exploring Psychology 8th Edition. Belmont: Wadsworth, Cengage Learning.

Pratama, P. \& Bintang, S. 2015. Penerapan Strategi Pembelajaran Pelatihan Industri (Training Within Industri) Terhadap Aktivitas dan Hasil Belajar Instalasi Motor Listrik. Jurnal Pendidikan Teknologi dan Kejuruan, 17 (2): 73-79.

Purwanto, E. 2014. Model Motivasi Trisula: Sintesis Baru Teori Motivasi Berprestasi. Jurnal Psikologi, 41 (2): 218-228.

Retnowati, D.R., Fatchan, A., \& Astina, I.K. 2016. Prestasi Akademik dan Motivasi Berprestasi Mahasiswa S1 Pendidikan Geografi Universitas Negeri Malang. Jurnal Pendidikan: Teori, Penelitian, dan Pengembangan, 1(3): 521-525.

Sathiyapriya, T. \& Vivek, N. 2013. Application of TWI (Training Within Industry) in Supply Chain Management. Journal of Contemporary Research in Management, 8(2): 1-8.

Suparno. 2009. Pengembangan Bahan Ajar Praktik Kejuruan Inovatif Untuk Meningkatkan Kemampuan Kognitif dan Psikomotorik Siswa Sekolah Menengah Kejuruan (SMK) Jurusan Teknik Bangunan. Bangunan: Teori, Praktek, Penelitian, dan Pengajaran Teknik Bangunan, 16 (1):?????

Wena, M. 2012. Setrategi Pembelajaran Inovatif Kontemporer Suatu Tinjauan Konseptual Operasional. Jakarta: Bumi Aksara Jakarta.

Wren, J., Renner, J., \& Gardhagen, R. 2009. Learning More With Demonstration Based Education. International Journal of Engineering Education, 25 (2): 374-3. 